A N N A L E S

UNIVERSITATIS MARIAE CURIE-SKŁODOWSKA

LUBLIN - POLONIA

VOL. LXXIV

SECTIO B

2019

AGATA ANTCZAK-STĘPNIAK

ORCID ID: 0000-0002-5858-2774

University of Łódź

Faculty of Economics and Sociology

agata.antczak@uni.lodz.pl

\title{
The Impact of Spatial Planning on Development Activity
}

Wpływ planowania przestrzennego na działalność deweloperską

\begin{abstract}
Abstrakt: Celem artykułu było zbadanie wpływu planowania przestrzennego na działalność deweloperską na przykładzie wybranych miast Polski. Analiza opisowa literatury przedmiotu, dostępnych danych statystycznych oraz informacji o przedsięwzięciach deweloperskich (samodzielnie zebranych przez autorkę) wykazała znaczne zróżnicowanie w powierzchni miast pokrytej planami oraz w liczbie realizowanych przez deweloperów inwestycji. Co do zasady deweloperzy chętniej prowadzą przedsięwzięcia w miejscu obowiązywania planów miejscowych, lecz zdarzają się też odmienne przypadki, co może wskazywać na błędną politykę gmin w zakresie planowania, zniechęcającą do prowadzenia na jej terenie inwestycji.
\end{abstract}

Słowa kluczowe: planowanie przestrzenne; działalność deweloperska; rynek mieszkaniowy

\begin{abstract}
The aim of the article is to examine the impact of spatial planning on development activity based on the example of selected cities of Poland. Descriptive analysis of the subject literature, available statistical data and information about development projects (collected by the author herself) shows a significant diversity in the area of cities covered by the plans and the number of investments implemented by developers. As a rule, developers are more willing to conduct projects in the place where local plans are in force, but there are also different cases, which may indicate a faulty communal policy in the field of planning, discouraging developers from undertaking investments in its area.
\end{abstract}

Keywords: spatial planning; development activity; residential market

\section{INTRODUCTION}

Spatial planning is a management tool used primarily to formulate goals and tasks of spatial policy, defining also the manner of their implementation (Brzeziński 2013). Therefore, it plays a key role in determining the medium and 
long-term development of specific areas as well as in promoting the rational use of land taking into account the interests of both public and private entities. An effective spatial policy can bring many direct benefits to investors, including improving the quality of space, which, in turn, contributes to property value growth, creating spatial order, ensuring investment stability, generating demand for property land for investments, or facilitating decision making (Krajewska et al. 2014). In practice, in the spatial planning of many units, certain trends are visible which make it inefficient, and which in many cases also contribute to the deterioration of the use of space. This applies in particular to erroneous initial assumptions and bureaucracy related to the enforcement of planning regulations. In relation to erroneous assumptions, it is important to properly determine the problem that we would like to solve using spatial planning. If we assume that in a given commune there is a deficit of flats accompanied by a constantly decreasing population, planning new housing undertakings may prove to be pointless and may even have negative consequences for its development. Bureaucracy often extends the entire investment process and, moreover, limits the possibility of achieving the assumed goals, because the goals and motives of individual decision-makers can be different from social goals. In addition, officials often fall into a routine, which also contributes to the devaluation of spatial planning in some units (Saey 2002). Some authors also emphasize that the Polish spatial planning system is ineffective because all planning acts, i.e. the concept of spatial development of the country, the spatial development plan of the voivodship or local plans, are passive. This means that they only define the way of land development but do not specify the actions that should be taken to achieve these assumptions (Sobieraj 2017).

The spatial policy conducted in that way may have a negative impact on the development activity carried out in individual communes. The developer, wanting to carry out any undertaking, in the early stages of the development process, must take into account the provisions of local plans or, in the situation of their absence, the decision on building conditions (BC).

The aim of the article is to examine the impact of spatial planning on development activity based on the example of selected cities of Poland. Descriptive analysis of the subject literature, available statistical data and information about development projects collected by the author herself shows a significant diversity in the area of cities covered by the plans and the number of investments implemented by developers. As a rule, developers are more willing to conduct projects in the place where local plans are in force, but there are also different cases, which may indicate a faulty communal policy in the field of planning, discouraging developers from undertaking investments in its area. 


\section{THE ROLE OF SPATIAL PLANNING IN THE DEVELOPMENT ACTIVITY}

Development activity, understood as a creative activity aimed at transforming a property to increase its value, is characterized by high complexity (Śmietana, Zagórska 2009). This complexity results, among other things, from the number of activities to be performed during the entire development process and entities participating in it. The developer seeking a suitable location for a particular project should check if in a given place local plans are in force. These are acts of local law of an optional nature, which means that they do not have to be drawn up for the entire territory of the commune, but their provisions are binding for everyone. On the basis of these plans, the developer is aware of whether it will be possible to carry out the planned investment in a given area, because the land use designation of individual properties is specified in them. Some information contained in the local plans, useful for choosing the right location, will be necessary for creating a building design. The information includes, among others: land development indexes, including the minimum and maximum intensity of development, the minimum share of biologically active area, the maximum construction height, the number of parking spaces, dimensions of buildings or their location relative to roads (Ustawa z dnia 27 marca 2003 r...). Sometimes, even the color of the tile is indicated. These regulations should promote the preservation or creation of spatial, urban and architectural order. Therefore, the provisions of local plans enforce a specific form of development and the task of the developer is to create a project that will meet these requirements, and at the same time bring the greatest profit. Lack of compliance of the project with the applicable regulations may contribute to the failure to obtain a building permit, and the project mismatched to the land property will limit the developer's profit. Abroad, to achieve both goals, developers often employ planners who, working together with architects, help maximize the use of the chosen space in accordance with local plans (Peiser, Hamilton 2012). But what if there is no local plan in a given place? Then the development process becomes more complicated. Namely, at the stage of seeking a suitable location, the developer can only use the provisions of the study on the commune's land use conditions and directions. It is an obligatory document but for investors its provisions are not binding. At this stage, it allows the developer to become acquainted with the form of building preferred in a given area. Before the final purchase of the land, the developer should, however, apply for a decision on $\mathrm{BC}$ which will determine whether the planned investment can be implemented in the selected location, and will also specify the building parameters allowed in this area. In order to 
obtain a decision on $\mathrm{BC}$, the developer must meet several conditions, i.e. at least one neighboring plot located along the same road must be built-up in order to determine the building parameters for the preservation of spatial order, access to a public road must be ensured, existing or planned technical infrastructure must be available. It is also important that there should be no need to transform agricultural and forest land into building land. In this decision, the head of the local authority, the mayor or the president, indicates the lines and building area, the width and height of the facade, as well as the roof geometry which should be included in the building design (Ustawa z dnia 27 marca 2003 r...). As in the case of non-inclusion of the provisions of local plans, without taking into account the decision on the $\mathrm{BC}$, the developer will not obtain a building permit. All the activities discussed above seem to be transparent, which means that in fact spatial planning should positively influence spatial order without significantly hampering development activity. In practice, however, it is not the case. Firstly, covering communes with local plans that can actually facilitate and, above all, accelerate the development process in Poland is low - around 30\%. The Supreme Audit Office also draws attention to this fact (NIK 2017). Secondly, the study on the commune's land use conditions and directions is of little importance, i.e. not having the character of a local law, and in the absence of local plans, it does not guarantee the implementation of objectives set in the spatial policy. In practice, decisions on building conditions are not always issued in accordance with their findings. This may cause negative implications for the developer who, for example, is carrying out a housing project, and alongside another investor, obtains a BC decision for the implementation of warehouse development. Such situations result in part from the criteria for issuing these decisions, which are not specified in the law, e.g.: what is the definition of "neighboring plot" or "area of analysis" (Brzeziński 2013). For example, in relation to the area of analysis, the implementing regulation to the act on spatial planning and development specifies only its minimum area. This means that in practice very large areas are considered to justify any function that the investor wants to achieve in a given location. On the other hand, the implementation of multi-family housing among single-family houses is justifiable in the same way. Such discretion in issuing $\mathrm{BC}$ decisions may, therefore, cause increased development activity. This is due to the fact that accessibility of property land, often much cheaper, is increasing. However, it should be noted that the said discretion may contribute to the dispersion of buildings, and this, in turn, to the increase in the cost of maintaining public infrastructure (Brzeziński 2013). Thus, the designation of the real estate is determined not by the authorities but by developers or other investors. In the absence of local plans, there is one more important issue to be addressed in 
relation to development activity, namely the waiting time for a decision on $\mathrm{BC}$. According to Polish legislation, it should be 60 days (Ustawa z dnia 14 czerwca $1960 \mathrm{r} .$. ). Meanwhile, in many communes, it ranges from a few to several months (in Łódź, about 9 months). This significantly extends the development process, and, at the same time, freezes the developer's capital.

The impact of spatial planning on development activity can be both positive and negative. It depends on how the local spatial policy is conducted in a given area.

\section{RESEARCH FIELD}

Taking into account the above-described implications, it can be assumed that planning regulations may affect the number and location of development projects implemented in particular communes. It is assumed that a coherent spatial policy, manifested in a large number of local plans, contributes to greater activity of developers. However, where decisions on $\mathrm{BC}$ have become a common surrogate of local plans, lower activity is expected due to the long waiting time for their issuance. To verify these hypotheses, five cities were analyzed in terms of their spatial policy and development activity. Due to the fact that development activity is focused primarily where the largest demand is expected, i.e. in large cities, the voivodship cities were the basis for choosing five surveyed units. Several local, economic, socio-demographic and resource-related factors were used to make the selection (Antczak-Stępniak 2015), i.e. the average level of gross wages, population, unemployment rate and average flat surface per person. The population along with the average level of remuneration inform us about the purchasing power in a given area. The higher these ratios, the more investments should be made in a given city. The opposite tendency can be observed in the case of the other two factors. A high unemployment rate is a source of risk for developers due to the difficulty of selling apartments, as well as a high surface area of flats per person, suggesting adequate saturation of this area in a given city.

The statistics presented in Table 1 allowed to distinguish cities that were to be subject to the analysis of the impact of spatial planning on development activity. Due to the fact that the largest cities of Poland are often analyzed (cf Antczak 2013), in this article, smaller voivodship cities were surveyed, i.e. the cities with average monthly gross wages ranging between PLN 3,900 and PLN 4,400, the population of over 150,000 and less than 400,000 , the unemployment rate above $4.1 \%$ (Łódź exception) and the average floor area of dwelling per 1 person below $27.5 \mathrm{~m}^{2}$ (Gorzów Wielkopolski and Bydgoszcz had been previously eliminated on the basis of other criteria). Finally, Torun was excluded from the analysis 
Tab. 1. Selected statistics that affect the dynamics of development activity shown on the example of 2017 (author's own study based on Local Data Bank)

\begin{tabular}{|l|c|c|c|c|}
\hline \multicolumn{1}{|c|}{ City } & Remuneration* & Population & $\begin{array}{c}\text { Unemployment } \\
\text { rate (in \%) }\end{array}$ & $\begin{array}{c}\text { Average floor area of } \\
\text { dwelling per 1 person* } \\
\text { (in m } \text { m }^{*}\end{array}$ \\
\hline Wrocław & $4,800.54$ & 638,586 & 2.2 & 34.1 \\
\hline Bydgoszcz & $3,950.95$ & 352,313 & 3.9 & 24.4 \\
\hline Toruń & $4,170.83$ & 202,562 & 5.2 & 25.7 \\
\hline Lublin & $4,169.46$ & 339,850 & 6.2 & 26.4 \\
\hline Gorzów Wielkopolski & $3,670.29$ & 124,295 & 2.6 & 27.0 \\
\hline Zielona Góra & $3,919.96$ & 139,819 & 3.4 & 29.5 \\
\hline Lódź & $4,230.12$ & 690,422 & 6.4 & 27.5 \\
\hline Kraków & $4,635.26$ & 767,348 & 2.8 & 27.8 \\
\hline Warszawa & $5,739.61$ & $1,764,615$ & 2.0 & 31.3 \\
\hline Opole & $4,378.37$ & 128,140 & 4.1 & 28.9 \\
\hline Rzeszów & $4,319.48$ & 189,662 & 5.6 & 27.3 \\
\hline Białystok & $3,967.71$ & 297,288 & 7.0 & 26.3 \\
\hline Gdańsk & $5,118.59$ & 464,254 & 2.9 & 27.7 \\
\hline Katowice & $5,274.86$ & 296,262 & 2.2 & 28.7 \\
\hline Kielce & $3,920.24$ & 196,804 & 5.8 & 24.8 \\
\hline Olsztyn & $4,254.72$ & 173,070 & 4.5 & 25.8 \\
\hline Poznań & $4,770.94$ & 538,633 & 1.4 & 30.4 \\
\hline Szczecin & $4,539.15$ & 403,883 & 3.2 & 27.6 \\
\hline & & & & \\
\hline
\end{tabular}

*data as of 2016

due to its different location in relation to the other cities included in the sample. Therefore, cities such as Lublin, Rzeszów, Kielce, Olsztyn and Białystok, which are the capitals of neighboring voivodships of Eastern Poland, were analyzed.

\section{SOURCES AND RESEARCH METHODS}

Information on the number of local plans and decisions on $\mathrm{BC}$ for residential construction in the examined cities for the years 2009-2016 came from the Local Data Bank of the Central Statistical Office. With reference to the size and location of development projects in these cities, the author carried out her own research, taking into account investments in progress, both multi-family and single-family ones. This information was collected on the basis of real estate websites (e.g. www.rynekpierwotny.pl, www.urbanity.pl) and websites of individual developers. In addition, the websites of the studied cities, their Public 
Information Bulletins, and, in the case of two cities, portals containing spatial information, i.e. the Municipal Spatial Information System of Białystok and the Geoportal Kielce, were used to analyze the location of the investments in the context of the areas covered by the plans.

\section{THE RESEARCH RESULTS AND DISCUSSION}

First of all, the conditions related to spatial planning were analyzed in the studied cities. Figure 1 presents the share of the area of the examined cities covered by current local plans.

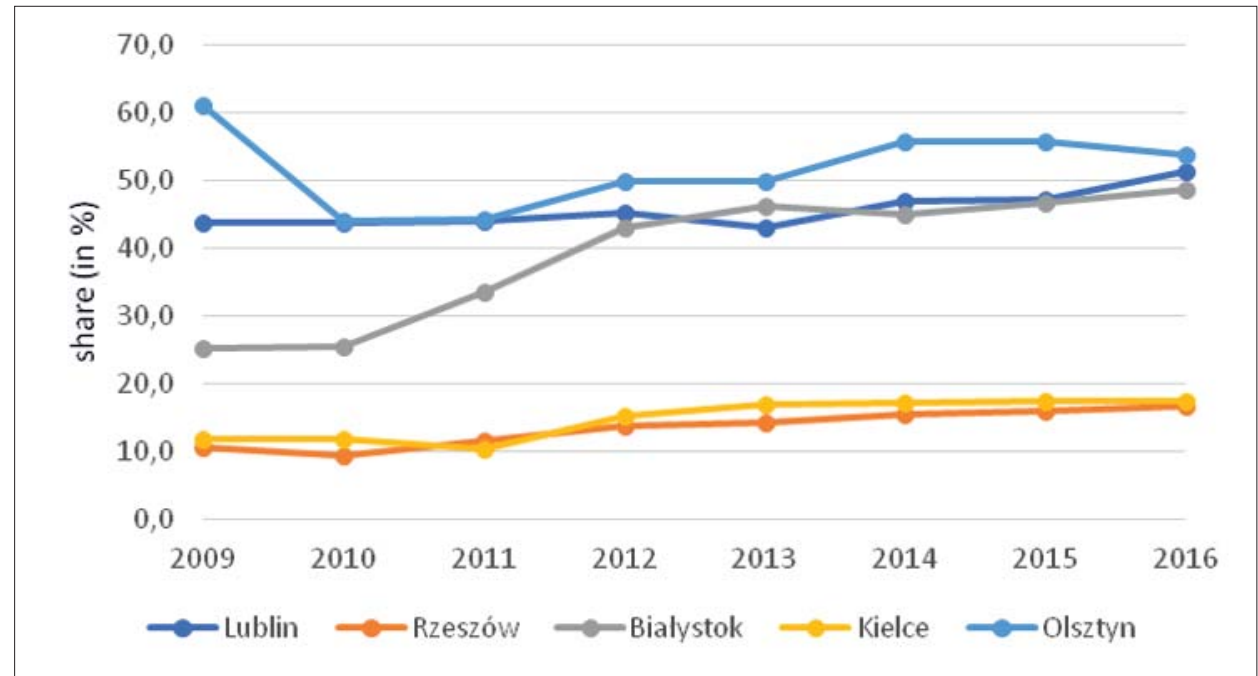

Fig. 1. Share of the area of the examined cities covered by local plans in their total area (author's own study based on Local Data Bank)

The information contained in Figure 1 shows that the level of coverage by the local plans in Lublin, Olsztyn and Białystok is similar and ranges from nearly $50 \%$ to $55 \%$. It is also worth noting that these are results that are far above the national average. In line with the hypotheses set out above, it should be assumed that development activity will be greater in these cities. Kielce and Rzeszów definitely differ in this respect from the other surveyed cities. In their case, the level of coverage with local plans is only $17-18 \%$. Such a low level may contribute to a greater number of issued decisions on BC. Figure 2 presents their number in relation to multi-family housing as well as single-family housing.

Figure 2 does not fully confirm the relationship described above. Namely, the majority of $\mathrm{BC}$ decisions for multi-family buildings were issued in Lublin 


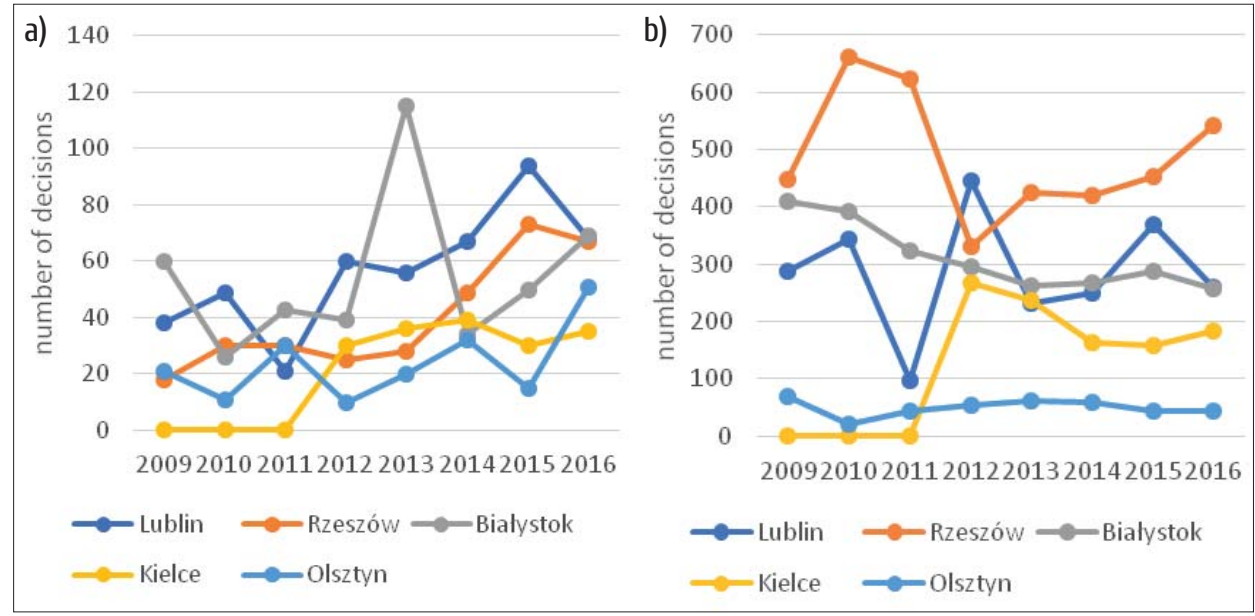

Fig. 2. Number of issued decisions on building conditions: a) for multi-family housing, b) for singlefamily housing (author's own study based on Local Data Bank)

and Białystok (i.e. where the level of coverage by plans was the highest), and for single-family housing - in Rzeszów. This may indicate, firstly, that some developers operating in these cities prefer to apply for building conditions on cheaper land, hoping, as highlighted in the previous points, that they will be able to build this development in a place where the study does not provide it, and secondly perhaps in these cities the waiting time for $\mathrm{BC}$ decisions is conducive to applying for several decisions at the same time. In both cases, Kielce and Olsztyn occupy the lowest positions, which is interesting considering the fact that Olsztyn has the highest level of coverage by plans and Kielce - the lowest.

The number of developers as well as the development undertakings in the examined cities is lower than in the largest cities in Poland. The largest number of development projects for sale (investments in progress and already completed) were identified in Lublin, i.e. 56, while the smallest number in Olsztyn - 25. The number of investments in progress is shown in Table 2.

The information presented in Table 2 shows that the development activity in the examined cities is raising, as more than half of the undertakings are currently in progress. Interestingly, apart from Rzeszów, multi-family buildings are mostly built. At the same time, the locations of these investments were analyzed to determine whether they were being implemented in areas covered by current local plans. The results of this research are presented in Table 3.

Only in Białystok, the spatial information system with the local plans applied enabled detailed analysis. In other cities, this study was significantly hampered by a poorly functioning system (Kielce) or the availability of graphic 
Tab. 2. The number of development investments identified in the examined cities* (author's own study)

\begin{tabular}{|l|c|c|}
\hline \multirow{2}{*}{ City } & \multicolumn{2}{|c|}{ Number of investments in progress } \\
\cline { 2 - 3 } & Multi-family buildings & Single-family buildings \\
\hline Białystok & 24 & 3 \\
\hline Kielce & 32 & 1 \\
\hline Lublin & 38 & 2 \\
\hline Olsztyn & 19 & 1 \\
\hline Rzeszów & 26 & 12 \\
\hline
\end{tabular}

*as of July-August 2018

Tab. 3. The number of investments in progress located in the area of application of local plans (as of August 2018) (author's own study)

\begin{tabular}{|l|c|}
\hline \multicolumn{1}{|c|}{ City } & Number of investments \\
\hline Białystok & 13 \\
\hline Kielce & 8 \\
\hline Lublin & 28 \\
\hline Olsztyn & 2 \\
\hline Rzeszów & 16 \\
\hline
\end{tabular}

attachments to the plans only in pdf format. Due to this fact, data concerning these cities may slightly differ from the actual situation because of the inability to thoroughly examine specific locations.

Comparing the information contained in Figures 1-2 and in Table 3, a large variation between the examined cities can be noted. Olsztyn has the largest area covered by plans according to Local Data Bank. Meanwhile, the study shows that only 2 out of 20 investments currently in progress are located within the area of local plans. Therefore, it would seem that developers in this city prefer acquiring low-cost land properties located in areas not covered by plans, and therefore must apply for a decision on BC. At the same time, it should be noted that in Olsztyn there is a very little number of these decisions issued. This may explain a small overall number of investments in this city. It turns out that in Olsztyn a small part of the city is designed for multi-family housing, which is usually implemented by developers. Even in the study on the commune's land use conditions and directions, more areas are focused on the development of single-family housing than multi-family housing. This is probably the reason for such low activity of developers. In Lublin, where also more than $50 \%$ of the city is covered by plans, investments made in the areas covered by them are much 
more numerous, namely 28 out of 40. In Białystok, also nearly half of the investments are carried out in the area where local plans are in force. In the case of cities characterized by a low, less than $20 \%$, share of the area covered by plans, there is also a large diversity of the analyzed problem - in Rzeszów 16 out of 38 investments, while in Kielce only 8 out of 33 investments are implemented in the areas covered by plans. In Kielce, however, the small area covered by the plans is designed for multi-family housing - most are service areas, green areas or single-family housing areas. This forces developers, as in Olsztyn, to apply for decisions on development conditions. It is interesting, however, what the reason for a small number of $\mathrm{BC}$ decisions in this city is, taking into account the above conclusions regarding local plans, and, at the same time, a significant number of investments.

At this point, one should also consider the possible impact of legal changes that may take place in the near future. This is about the so-called special act on housing, i.e. the Act of 5 July 2018 on facilitating the preparation and implementation of housing investments and accompanying investments. The Act should contribute to the use of agricultural land within the administrative borders of cities as well as unused post-military, post-industrial areas, etc. Thanks to this, housing developers will have greater access to land, which, in turn, may contribute to a drop in land prices and further growth of development activity. In this way, the government also wants to encourage developers to participate in the implementation of the "Mieszkanie Plus" program (Wielgo 2018). In the case when an investment meets the requirements of the Special Act, the provisions of the Act on spatial planning and land development will not apply, and in addition, these investments could be implemented irrespective of the provisions of local plans. However, this must be in line with the provisions of the study on the commune's land use conditions and directions. The developer implementing the investment in the framework of the special procedure, according to the assumptions of the project providers, will not have to wait several months for the investment, but must apply for a decision on determining the location of the housing project. This decision should be issued within 60 days, after public consultations (Ustawa $\mathrm{z}$ dnia 5 lipca 2018 r...). It should be noted that the statutory time of issuing a $\mathrm{BC}$ decision is also 60 days, with no obligation to consult the public. The question then arises whether the time of obtaining all necessary permits will actually be shortened. In the author's opinion, there are three types of risks associated with the provisions of the Special Act in the context of development activity. Namely, it can contribute to the formation of urban chaos. Developers will build where they can buy a cheaper plot. It may also cause problems with the sale of apartments located in not a very pleasant neighborhood. Secondly, 
there is a fear that the period of obtaining the necessary decisions will not be shortened. Thirdly, the question arises whether facilitations in access to land are so necessary taking into account unfavorable population forecasts and studies showing that too much land is intended for housing development (Kowalewski 2012). The only positive aspect that can be seen in these provisions is the fact that $\mathrm{BC}$ decisions may be issued despite contradictions with the findings of the study, while in the case of a decision to determine the location of a residential investment, these provisions will have to be compatible.

\section{CONCLUSIONS}

In conclusion, the impact of spatial planning on development activity is quite difficult to specify. Undoubtedly, both local plans and decisions on building conditions play a significant role in the growth of property development. However, their influence depending on the spatial policy in a given commune may be different - both positive and negative. In three of the five studied cities, developers prefer to implement investments in a place where local plans are in force. This shortens significantly the entire development process, thanks to which the developer quickly unlocks its capital and can implement new investments. This is particularly evident in Rzeszów, where the level of coverage by local plans is low, and yet many developers choose the locations for which they are valid. However, there are cities in which the coverage of plans is high, while development activity is developing to a negligible extent. Olsztyn and Kielce are examples of such cities.

Based on the research, according to the author, it is necessary to revise the spatial policy of some studied cities, in particular Olsztyn, Kielce and Rzeszów. In these cities, the dependencies between spatial planning and the growth of development activity are the least transparent. Firstly, it is necessary to increase the level of coverage by plans in two of them in order to facilitate the investment process. Secondly, it is necessary to limit discretion in issuing decisions on $\mathrm{BC}$, as well as lobbying that some investors will probably use to achieve the assumed goal. This will also contribute to the improvement of spatial order in these cities. Thirdly, it seems necessary to verify the designation of the areas in the current local plans - whether it is actually adapted to the city's needs and conditions, or is determined, just like in the decisions on building conditions, only by the developer's point of view. 


\section{REFERENCES}

Antczak A. 2013. Developers' activity in selected cities of Poland - a comparative analysis. Real Estate Management and Valuation 21(1).

Antczak-Stępniak A. 2015. Local factors influencing the growth of development activity in selected cites of Poland. Real Estate Management and Valuation 23(3). https://doi.org/10.1515/ remav-2015-0027

Brzeziński C. 2013. Wybrane problemy planowania przestrzennego w Polsce. Acta Universitatis Lodziensis. Folia Oeconimica 289.

Kowalewski A. 2012. Quoted after: Stangel M. 2013. Kształtowanie wspótczesnych obszarów miejskich w kontekście zrównoważonego rozwoju. Gliwice: Wydawnictwo Politechniki Śląskiej.

Krajewska M., Źróbek S., Šubic-Kovač M. 2014. The role of spatial planning in the investment process in Poland and Slovenia. Real Estate Management and Valuation 22(2). https://doi. org/10.2478/remav-2014-0017

Najwyższa Izba Kontroli, 2017. NIK o systemie gospodarowania przestrzenia gminy jako dobrem publicznym. Online: https://www.nik.gov.pl/aktualnosci/nik-o-systemie-gospodarowania-przestrzenia-gmin.html (access: 6.08.2018).

Peiser R.B., Hamilton D. 2012. Professional Real Estate Development. Washington: Urban Land Institute.

Saey P. 2002. Spatial planning as large-scale practical project: The problem of effective governance. Belgeo: Revue Belge de Géographie 3. Governance and geography.

Sobieraj J. 2017. Impact of spatial planning on the pre-investment phase of the development process in the residential construction field. Archives of Civil Engineering 63(2). https://doi. org/10.1515/ace-2017-0020

Śmietana K., Zagórska E. 2009. Deweloper jako profesjonalny uczestnik rynku nieruchomości. In: H. Henzel (ed.), Strategie inwestowania na rynku nieruchomości (pp. 160-166). Katowice: Wydawnictwo AE.

Ustawa z dnia 14 czerwca 1960 r. - Kodeks postępowania cywilnego (Dz.U. z 1960 r. nr 30 poz. 168) (The Act of 14 June 1960- Code of Civil Procedure [Journal of Laws 1960, no. 30 item 168]).

Ustawa z dnia 27 marca 2003 r. o planowaniu i zagospodarowaniu przestrzennym (Dz.U. z 2003 r. nr 80 poz. 717, z późn. zm.) (The Act of 27 March 2003 on spatial planning and land development [Journal of Laws 2003, no. 80 item 717, as amended]).

Ustawa z dnia 5 lipca 2018 r. o ułatwieniach w przygotowaniu i realizacji inwestycji mieszkaniowych i inwestycji towarzyszących (Dz.U. z 2018 r. poz. 1496) (The Act of 5 July 2018 on facilitating the preparation and implementation of housing investments and accompanying investments [Journal of Laws 2018, no. 80 item 1496]).

Wielgo M. 2018. Specustawa mieszkaniowa: przez 10 lat ułatwienia dla inwestorów mieszkaniowych. Online: https://www.muratorplus.pl/biznes/prawo/pozwolenie-na-budowe-wedlugspecustawy-mieszkaniowej-zastapi-prawo-budowlane-aa-pXy4-dfDw-P6Sz.html (access: 2.08.2018). 